\title{
VARIABLE CAPACITY ABSORPTION COOLING SYSTEM PERFORMANCE FOR BUILDING APPLICATION
}

\author{
Y. Anand ${ }^{1}$, A.Gupta ${ }^{1}$, S.K. Tyagi ${ }^{2}$, S. Anand ${ }^{1 * *}$
}

\begin{abstract}
The increasing energy costs and environmental awareness call for a shift towards some interesting energy alternatives preferably the use of renewable energy. The present study investigates the impact of varying cooling capacity and other operating parameters in a single-effect absorption refrigeration system, using the concept of energy and exergy as a building heating/cooling alternative. The solar heat is used as an input to the generator of absorption refrigeration system. The results obtained from investigation revealed that variation in cooling capacity influences coefficient of performance (COP), exergy loss in different components as well as exergy efficiency. The values of $\mathrm{COP}_{\text {cooling }}$ and $\mathrm{COP}_{\text {heating }}$ lies in the range of 0.71-0.89 and 1.71-1.89 respectively for variations in cooling capacities ranging from $1 \mathrm{TR}$ to $20 \mathrm{TR}$ at maximum generator temperature of $80^{\circ} \mathrm{C}$. However, exergy efficiency of the system lies in the range of 0.32-0.41 for same variation in cooling capacities. It has also been established that an increase in evaporator temperature and at maximum cooling capacity both $\mathrm{COP}_{\text {cooling }}$ and $\mathrm{COP}_{\text {heating }}$ shows an increasing trend. The exergy efficiency also shows maximum value at the highest cooling capacity at a particular evaporator temperature which further with an increase in evaporator temperature shows a decreasing trend. The irreversibility behavior in all the components i.e., solution heat exchanger, absorber, generator, evaporator and condenser shows an expected trend with the variation in cooling capacity. Hence, use of the above mentioned system as a heating and/or cooling alternative for buildings is suggested.
\end{abstract}

Keywords: Absorption Refrigeration System, Coefficient of Performance, Exergy Analysis, Exergy Efficiency, Solar Heat

\section{INTRODUCTION}

The refrigeration systems are indispensible across the globe for various domestic and industrial applications like storage of food, beverages, pharmaceuticals etc. and also ensure thermal comfort inside the built environment [1-3]. A global increase in the population has led to the massive constructions, further leading to increase in the cooling demand thus increasing the installation of large number of refrigeration systems, requiring energy for their operations. Also, during the past years, the amount of time spent indoor (inside the building, either home or office) has also increased considerably, leading to the requirement of establishing and ensuring proper thermal comfort and thus making them the largest consumer of energy [4-6]. Only conventional means of energy cannot suffice the demand thus generated, as being a developing nation industrial sector can also not be neglected. So, alternative and non-polluting generation of energy from renewable energy sources is strictly stressed upon as it is the need of the hour [7, 8]. To accommodate these, strict rules and regulations regarding the energy and environment have been proposed from time to time with periodic modifications [9]. Many nations restrict the use of conventional hydrogenated fluorocarbons (HFCs) and chlorinated fluorocarbons (CFCs) as refrigerants because of their global warming as well as ozone depleting behavior. The energy and environment saving trends has promoted the development of new technologies for sustainable development [10]. In this study the absorption refrigeration systems as an alternative to mechanical refrigeration systems, is proposed and analyzed for building applications. Unlike, mechanical refrigeration systems, absorption refrigeration systems cause no ozone depletion because they don't use any CFCs or HFCs refrigerant as working fluid and also reduce the electricity consumption [11-13]. The absorption refrigeration system represents a unique technology for cooling and heating application but suffers a drawback of lower COP (0.5-0.7 for single effect and 1.2-1.5 for double effect systems) [14, 15]. The operation of absorption systems using nonconventional energy or low grade energy sources like solar energy, geothermal energy, biomass, waste heat This paper was recommended for publication in revised form by Regional Editor Sandip Kale ${ }^{1}$ School of Energy Management, Shri Mata Vaishno Devi University, Katra-182320 (J\&K), India

${ }^{2}$ Centre for Energy Studies, Indian Institute of Technology (IIT) Delhi, Hauz Khas-110016, New Delhi, India ${ }^{\star} E$-mail address anandsanjeev12@gmail.com; guptaankush83@gmail.com Manuscript Received 9 September 2016, Accepted 11 December 2016 
from the industries etc. outweighs its low $\mathrm{COP}$ and also reduces stress on the conventional energy. However, drawbacks of the absorption refrigeration systems are its heavy weight, relatively high investment, etc.

Many researchers have carried out work in the field of different types of refrigeration and air conditioning systems. The low temperature energy source based refrigeration and air conditioning system was evaluated and the results obtained indicate acceptable performance with respect to design and operating parameters [16 - 19].The second law analysis to locate losses meant for the optimization in different types of absorption refrigeration systems revealed that certain components need modifications for improving performance of the system [20 - 23].An experimental investigation of design and operation of a thermo-gravity pump (thermally activated pump) in a novel single stage $\mathrm{LiBr}-\mathrm{H}_{2} \mathrm{O}$ vapor absorption system to reduce energy costs of mechanical pumps was carried out [24]. The system involves two thermally activated valves for the circulation of working fluids and a novel regenerative heat exchanger to improve the effectiveness of generator as well as absorber. In another study, a detailed analysis of a liquid-vapor heat exchanger (LVHX) in a R134aDMAC vapor absorption refrigeration system for sub-zero temperature applications by varying various operating parameters revealed that an increase in importance of LVHX with a decrease in evaporator temperature as well as rectifier efficiency. However, rectifier efficiency also influences the heat transfer which helps in sizing the system [25]. Again, an experimental investigation of a 1TR compact absorber bubble absorption system using R134a-DMF was carried out to analyze the effect of various operating parameters on heat and mass transfer effectiveness, overall heat transfer coefficient and volumetric mass transfer coefficient and the potential outcomes revealed that heat and mass transfer effectiveness of absorber is better at lower circulation ratios and higher generator temperatures [26]. A correlation based on experimental data for volumetric mass transfer coefficient has also been developed using multi-linear regression tool.

In another study, performance evaluation of a vapor absorption refrigeration system using ionic liquid ammonia and water as co-solvent revealed that water when used as a co-solvent helps in reducing circulation ratio and subsequently the size of equipment subsequently decreasing the performance of a system slightly [27].

In a simple theoretical and computational fluid dynamics (CFD) analysis performance of insulating paints was tested which was based on a function of different parameters. The benefits of using insulating paints was shown to be minimal; even under highly favorable conditions and depicts the reduction in energy consumption by less than $1 \%$ [28].

The experimentally impact analysis of cool roof technology based on insulating paints as an alternative to thermal comfort of the office buildings was also analyzed considering the impact of heat transfer rate to the building envelope and findings indicate that use of such method as a cool roof technique is beneficial to maintain comfort level of the building which purely depends on the environment/ambient temperature conditions [29]. An existing cogeneration system driven by biogas internal combustion engines was investigated by energy and exergy analyses. The results revealed that minimal thermodynamic efficiency of CHP system must be replaced with parameters relating to the second law of thermodynamics [30].

The literature reviewed highlights the application of second law for the evaluation of vapor absorption systems with various options but the comparative analysis of such system with variation in the cooling capacity and that too for a building application is scant.

Based on shortcomings in the reviewed literature, present analysis evaluates the influence of various operating parameters using the concept of energy and exergy in a single-effect ammonia-water absorption system for building air conditioning system. The effect of the variation of cooling capacity on COP, exergy efficiency, exergy loss in different components and mass flow rate is analyzed and discussed. The effect on COP and exergy efficiency with respect to the variation in generator temperature, evaporator temperature as well as absorber and condenser temperature has also been analyzed and discussed. The effect of the variation in ambient temperature on the exergy loss in different components and exergy efficiency has also been discussed.

\section{SYSTEM DESCRIPTION}

The system to be analyzed is single-effect ammonia water vapor absorption system and is shown in Figure 1. The proposed system uses solar heat as an energy source to the generator of the system besides ammonia as a refrigerant and water as an absorbent. The system consists of a generator, condenser, an absorber, an evaporator, solution heat exchanger, throttling device, pressure reducing valve and pump. The solution rich in refrigerant exits the absorber (7) and is pumped through the solution pump (8) to the solution heat exchanger and is heated by the weak solution that comes from the generator. The strong solution enters the generator (1) 
where ammonia is raised in to vapors by external heat supply and is separated from the solution. The ammonia vapor exits the generator (2) and weak solution returns to absorber through the solution heat exchanger (3-9) and lowers its pressure through pressure reducing valve (9-10). The ammonia vapors are condensed in the condenser and latent heat of condensation is released in to the cooling water flowing through the condenser. The ammonia liquid is produced in the condenser (4) is at higher pressure and is passed through the throttling device (4-5) to reduce its pressure. At this low pressure saturated liquid ammonia enters the evaporator and is again converted to vapors by absorbing the latent heat from the chilled water circulated between evaporator and cooling space. The refrigerant vapor produced enters the absorber (6) and absorbed by strong solution in the absorber where the heat of absorption is released to the surrounding fluid (water or air) and strong solution released through the absorber either in saturated or in a slightly sub-cooled state. This process is continued and the refrigerating effect is produced.

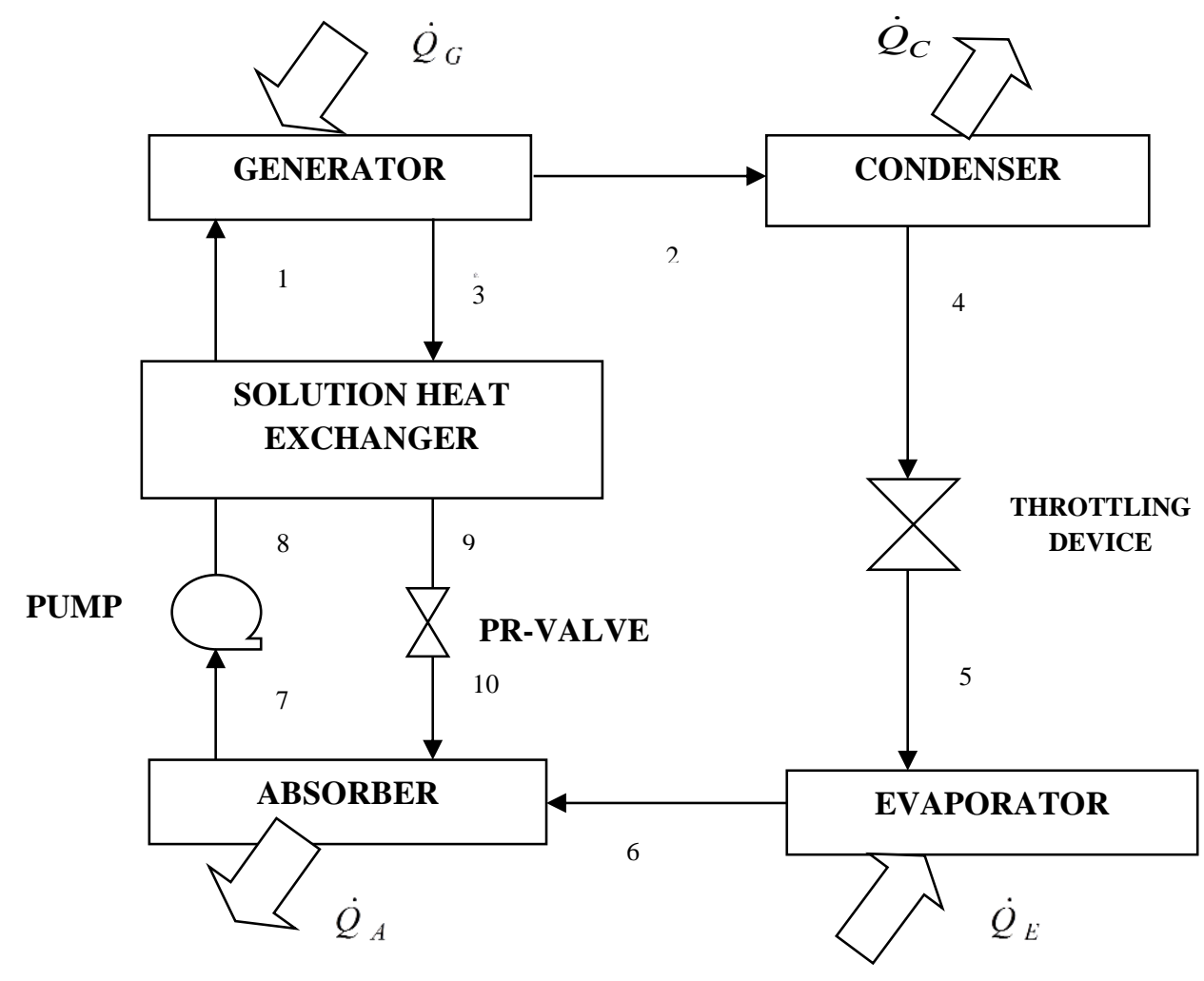

Figure 1. Schematic diagram of a single-effect ammonia-water vapor absorption refrigeration system

Certain assumptions for the simulation study are:

a). Solution leaving the absorber and generator are assumed to be saturated in equilibrium conditions at their respective temperatures and concentrations.

b). The refrigerant leaving the condenser and evaporator are assumed to be saturated.

c). Refrigerant vapor leaving the generator is considered to be superheated.

d). The reference enthalpy $\left(h_{0}\right)$ and the entropy $\left(s_{0}\right)$ used for calculating the exergy of the working fluid at an environmental temperature and pressure of $25^{\circ} \mathrm{C}$ and 1 bar respectively.

e). The mass flow rate of refrigerant at state points $2,4,5 \& 6$ is assumed to be same.

f). The mass flow rate of weak solution at state points $3,9 \& 10$ is assumed to be same.

g). The mass flow rate of strong solution at state points $1,7 \& 8$ is assumed to be same.

h). The pressure drop within the solution and refrigerant valves is negligible

\section{THERMODYNAMIC ANALYSIS}

The principles of mass conservation, first and second laws of thermodynamics are applied to each component of the system for carrying out thermodynamic analysis of an absorption system. The governing equations of mass and material balance for steady state operation of the system are given below [31]: 


$$
\begin{aligned}
& \sum \dot{m}_{i}-\sum \dot{m}_{o}=0 \\
& \sum(\dot{m} x)_{i}-\sum(\dot{m} x)_{o}=0
\end{aligned}
$$

Where, ' $\dot{m}$ ' is the mass flow rate and ' $x$ ' is concentration of ammonia in the solution. The First law of thermodynamic yields the energy balance of each component of the absorption system mentioned below as:

$$
\sum(\dot{m} h)_{i}-\sum(\dot{m} h)_{o}+\left[\sum \dot{Q}_{i}-\sum \dot{Q}_{o}\right]_{ \pm} \dot{W}=0
$$

\section{ENERGY ANALYSIS}

The energy balance equations of various components are calculated and respective heat load values are mentioned in Table 2 based on various assumed parameters listed in Table 1. The performance of the refrigeration system can be calculated in terms of COP and therefore actual COP of absorption chiller is calculated from the equation given below:

$$
\text { COP } \text { Cooling }=\frac{\dot{Q}_{E}}{\left(\dot{Q}_{G}+\dot{W}_{P}\right)}
$$

Where ' $\dot{Q}_{E}$ ' is cooling effect and ' $\dot{Q}_{G}$ 'is energy supplied to the generator/ heat source. The pump work ' $\dot{W}_{P}{ }^{\prime}$ calculated to be very small as compared to heat supplied to the generator and hence neglected in calculation part of COP of the system. The net refrigerating effect is then heat absorbed by refrigerant in evaporator to total energy supplied to generator and can be calculated from the equation given below:

$$
\text { COP }{ }_{\text {cooling }}=\frac{\dot{Q}_{E}}{\dot{Q}_{G}}
$$

The system can also be used for heating purposes and COP the system is given below:

$$
C O P_{\text {heating }}=\frac{\dot{Q}_{C}+\dot{Q}_{A}}{\dot{Q}_{G}}
$$

Where, ' $\dot{Q}_{C}$ ' \& ' $\dot{Q}_{A}$ ' are heat rejected from condenser and absorber respectively to water or air and ' $\dot{Q}_{G}$ ' is the energy supplied to generator/ heat source. The component wise energy balance of the absorption system is given as:

\section{Energy Balance at Generator}

$$
\dot{Q}_{G}-\dot{m}_{2} h_{2}-\dot{m}_{3} h_{3}+\dot{m}_{1} h_{1}=\mathrm{O}
$$

\section{Energy Balance at Absorber}

$$
\dot{Q}_{A}-\dot{m}_{2} h_{6}-\dot{m}_{3} h_{10}+\dot{m}_{1} h_{7}=0
$$

\section{Energy Balance at Condenser}

$$
\dot{Q}_{C}=\dot{m}_{2}\left(h_{2}-h_{4}\right)
$$


Energy Balance at Evaporator

$$
\dot{Q}_{E}=\dot{m}_{2}\left(h_{6}-h_{5}\right)
$$

\section{Energy Balance at Solution Heat Exchanger}

$$
\dot{Q}_{S H E}=\dot{m}_{3}\left(h_{3}-h_{9}\right)=\dot{m}_{1}\left(h_{1}-h_{8}\right)
$$

\section{Energy balance at valves}

$$
\begin{aligned}
& \boldsymbol{h}_{4}=\boldsymbol{h}_{5} \\
& \boldsymbol{h}_{9}=\boldsymbol{h}_{10}
\end{aligned}
$$

The equations (12) \& (13) are the results of isenthalpic conditions.

Effectiveness of heat exchanger is defined as ratio of actual heat transfer to maximum possible heat transfer. Accordingly, effectiveness of solution heat exchanger is given below:

$$
\varepsilon=\frac{\left(h_{3}-h_{9}\right)}{\left(h_{3}-h_{9^{\prime}}\right)}
$$

Where, ' $h_{9}=-115.8 \mathrm{~kJ} / \mathrm{kg}$ ' represents enthalpy of minimum heat capacity stream (strong solution) at the exit of heat exchanger when cooled to the temperature of cold stream (weak solution) entering the heat exchanger.

\section{EXERGY ANALYSIS}

Exergy can be defined as maximum theoretical work, derivable by interaction of an energy source with the environment and can be used for understanding irreversible nature of real thermal processes. As exergy measures process imperfection, therefore optimum operating conditions can be easily determined. The principle irreversibility in a process leading to these losses is due to various factors such as friction, heat transfer under temperature difference and unrestricted expansion. The physical exergy component is associated with the work obtainable in bringing a stream of matter from an initial state to a state that is in thermal and mechanical equilibrium with the environment [31]. The generalized equation is given below as:

$$
\Psi=\min \left[\left(h-h_{o}\right)-T_{o}\left(s-s_{o}\right)\right]
$$

Where, ' $\Psi$ 'is the exergy of fluid at temperature ' $T$ '. The terms ' $h$ ' and ' $s$ ' represent enthalpy and entropy of the fluid, whereas, ' $h_{o}$ ' and ' $s_{o}$ ' represents enthalpy and entropy of the fluid at environmental temperature ' $T_{o}$ ' .The exergy balance equations of different components of the absorption system are given as:

\section{Exergy Balance at Generator}

$\Psi_{G}=\dot{m}_{1}\left[\left(h_{1}-h_{o}\right)-T_{o}\left(s_{1}-s_{o}\right)\right]-\dot{m}_{2}\left[\left(h_{2}-h_{o}\right)-T_{o}\left(s_{2}-s_{o}\right)\right]-\dot{m}_{3}\left[\left(h_{3}-h_{o}\right)-T_{o}\left(s_{3}-s_{o}\right)\right]+\dot{Q}_{G}\left(1-\frac{T_{o}}{T_{G}}\right)$

\section{Exergy Balance at Absorber}

$\Psi_{A}=\dot{m}_{2}\left[\left(h_{6}-h_{0}\right)-T_{0}\left(s_{6}-s_{0}\right)\right]+\dot{m}_{3}\left[\left(h_{10}-h_{o}\right)-T_{o}\left(s_{10}-s_{0}\right)\right]-\dot{m}_{1}\left[\left(h_{7}-h_{o}\right)-T_{o}\left(s_{7}-s_{0}\right)\right]-\dot{Q}_{A}\left(1-\frac{T_{o}}{T_{A}}\right)$ 
Exergy Balance at Evaporator

$$
\Psi_{E}=\dot{m}_{2}\left[\left(h_{6}-h_{5}\right)-T_{o}\left(s_{6}-s_{5}\right)\right]+\dot{Q}_{E}\left(1-\frac{T_{o}}{T_{E}}\right)
$$

\section{Exergy Balance at Condenser}

$$
\Psi_{C}=\dot{m}_{2}\left[\left(h_{2}-h_{4}\right)-T_{o}\left(s_{2}-s_{4}\right)\right]-\dot{Q}_{C}\left(1-\frac{T_{o}}{T_{C}}\right)
$$

\section{Exergy balance at Solution heat exchanger}

$$
\Psi_{S H E}=\dot{m}_{3}\left[\left(h_{3}-h_{o}\right)-T_{o}\left(s_{3}-s_{o}\right)\right]-\dot{m}_{3}\left[\left(h_{9}-h_{o}\right)-T_{o}\left(s_{9}-s_{o}\right)\right]
$$

\section{EXERGY EFFICIENCY}

The second law performance of the system can be measured in terms of exergy efficiency (rational efficiency) which is expressed below in Equation 21 [22] and is defined as ratio between the net exergy produced by evaporator (desired exergy output) and input exergy to generator plus mechanical work of solution pump.

$$
\eta_{\psi}=\frac{\dot{Q}_{E}\left|\left(1-\frac{T_{O}}{T_{E}}\right)\right|}{\dot{Q}_{G}\left|\left(1-\frac{T_{O}}{T_{G}}\right)\right|}
$$

Where, ' $\eta_{\Psi}$ ' is the exergy efficiency, ' $\dot{Q}_{E}$ ' is cooling effect and ' $\dot{Q}_{G}$ ' is energy supplied to the generator/ heat source.

\section{RESULTS AND DISCUSSION}

Engineering Equation Solver (EES) [32] software has been used to develop a program for carrying out energy and exergy analysis of a single-effect ammonia water vapor absorption refrigeration system. The effect of variation in cooling capacities as well as operating parameters on the performance of vapor absorption refrigeration system for air-conditioning applications in buildings has been analyzed in the present analysis. Subroutines from the external library file of EES have been used for calculating the properties of ammonia and water. Add in function of the external library is used to calculate thermodynamic properties of the refrigerant at different state points in the system. The different conditions and parameters used for the computation of results are listed in the Table 1 which subsequently calculates the values of the enthalpy, concentration, temperature, entropy etc. and are listed in Table 3.

In the simulation study, the input parameters are taken as $\mathrm{T}_{\mathrm{E}}=5^{\circ} \mathrm{C}, \mathrm{T}_{\mathrm{C}}=\mathrm{T}_{\mathrm{A}}=25^{\circ} \mathrm{C}, \mathrm{T}_{\mathrm{G}}=80^{\circ} \mathrm{C}$ \& cooling capacity $=3.516 \mathrm{~kW}$. The results obtained from simulation revealed that the highest heat load occurs in solution heat exchanger followed by generator and absorber (Table 2). The heat load in a condenser is slightly higher than that of an evaporator, due to the superheating property of the inlet ammonia vapors in the condenser. The results from analysis are presented graphically in the Figures 2-9. Figure 2, depicts the variation of $\mathrm{COP}_{\text {cooling, }} \mathrm{COP}_{\text {heating }}$ and exergy efficiency with the cooling capacity at maximum generator temperature $\left(\mathrm{T}_{\mathrm{E}}=\right.$ $5^{\circ} \mathrm{C}, \mathrm{T}_{\mathrm{A}}=\mathrm{T}_{\mathrm{C}}=25^{\circ} \mathrm{C} \& \mathrm{~T}_{\mathrm{G}}=80^{\circ} \mathrm{C}$ ) and it becomes evident from the figure that analyzed performance parameters shows an increasing trend with the variation in cooling capacity. The maximum value of $\mathrm{COP}_{\text {cooling }}$ and

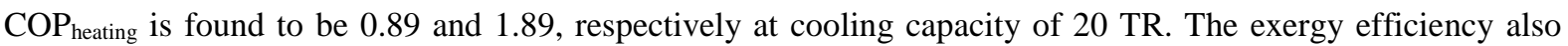
shows an increasing trend and the maximum value obtained is 0.41 at cooling capacity of 20 TR. The behavior of $\mathrm{COP}_{\text {cooling }}$ can be explained on the fact that at maximum generator temperature and an increase in cooling capacity, the temperature of refrigerant flowing through the generator increases which leads to an increase in the generation as well as transfer rate of the refrigerant vapors and hence improves COP of the system. The behavior of $\mathrm{COP}_{\text {heating }}$ can be explained on the fact that at maximum generator temperature and cooling capacity there will be an increase in the absorber as well as condenser outlet temperatures, because of an increase in flow 
Table 1. Operating conditions and fixed parameters adopted for cycle simulation

\begin{tabular}{|l|c|}
\hline Operating parameters & Fixed values \\
\hline Cooling capacity & $1-20 \mathrm{TR}$ \\
\hline Generator pressure & $10.7 \mathrm{bar}$ \\
\hline Evaporator pressure & $2.7 \mathrm{bar}$ \\
\hline Generator temperature & $278.15 \mathrm{~K}$ \\
\hline Evaporator temperature & $298.15 \mathrm{~K}$ \\
\hline Condenser temperature & $298.15 \mathrm{~K}$ \\
\hline Absorber temperature & $0.13 \mathrm{~kg} / \mathrm{s}$ \\
\hline Mass flow rate of strong solution $\left(\dot{m}_{1}\right)$ & $0.003144 \mathrm{~kg} / \mathrm{s}$ \\
\hline Mass flow rate of refrigerant $\left(\dot{m}_{2}\right)$ & $0.1269 \mathrm{~kg} / \mathrm{s}$ \\
\hline Mass flow rate of weak solution $\left(\dot{m}_{3}\right)$ & $298.15 \mathrm{~K}$ \\
\hline Ambient temperature & $1 \mathrm{bar}$ \\
\hline Ambient pressure & \\
\hline
\end{tabular}

Table 2. Heat exchanged in different components $\left(\mathrm{T}_{\mathrm{E}}=5^{\circ} \mathrm{C}, \mathrm{T}_{\mathrm{A}}=\mathrm{T}_{\mathrm{C}}=25^{\circ} \mathrm{C}, \mathrm{T}_{\mathrm{G}}=80^{\circ} \mathrm{C} \&\right.$ cooling capacity $=$ $3.516 \mathrm{~kW})$

\begin{tabular}{|c|c|c|}
\hline S. No & Component & Heat Load (kW) \\
\hline 1. & Generator & 4.925 \\
\hline 2. & Evaporator & 3.516 \\
\hline 3. & Condenser & 4.002 \\
\hline 4. & Absorber & 4.439 \\
\hline 5. & Solution Heat Exchanger & 31.35 \\
\hline \multicolumn{2}{|c|}{} & 0.714 \\
& Cooling Coefficient of Performance ( $\left.\mathrm{COP}_{\text {cooling }}\right)$ & 1.714 \\
\hline
\end{tabular}

Table 3. General solution properties and results obtained from the thermodynamic simulation $\left(T_{\mathrm{E}}=5^{\circ} \mathrm{C}, \mathrm{T}_{\mathrm{A}}=\right.$ $\mathrm{T}_{\mathrm{C}}=25^{\circ} \mathrm{C}, \mathrm{T}_{\mathrm{G}}=80^{\circ} \mathrm{C} \&$ cooling capacity $=3.516 \mathrm{~kW}$ )

\begin{tabular}{|c|c|c|c|c|c|c|c|c|}
\hline $\begin{array}{c}\text { State } \\
\text { Point }\end{array}$ & $\begin{array}{c}\text { Temperature } \\
(\boldsymbol{T})(\mathbf{K})\end{array}$ & $\begin{array}{c}x \\
(\boldsymbol{\%} \\
\mathbf{N H 3})\end{array}$ & $\begin{array}{c}\text { Pressure } \\
(\mathbf{p}) \\
(\mathbf{b a r})\end{array}$ & $\begin{array}{c}\text { Entropy } \\
(\mathbf{s}) \\
(\mathbf{k J} / \mathbf{k g}-\mathbf{K})\end{array}$ & $\begin{array}{c}\text { Enthalpy } \\
(\boldsymbol{h}) \\
(\mathbf{k J} / \mathbf{k g})\end{array}$ & $\begin{array}{c}\text { Internal } \\
\mathbf{e n e r g y} \\
(\mathbf{k J} / \mathbf{k g})\end{array}$ & $\begin{array}{c}\text { Specific } \\
\mathbf{v o l u m e} \\
\left(\mathbf{m}^{\mathbf{3}} / \mathbf{k g}\right)\end{array}$ & $\begin{array}{c}\text { Exergy } \\
(\mathbf{k W})\end{array}$ \\
\hline 1 & 353.1 & 0.34 & 10.7 & 1.013 & 142.7 & 141.4 & 0.001196 & -20.09 \\
\hline 2 & 338.1 & 0.9819 & 10.7 & 4.592 & 1377 & 1228 & 0.1399 & 0.0428 \\
\hline 3 & 358.1 & 0.3998 & 10.7 & 1.059 & 150.9 & 149.6 & 0.00124 & -20.3 \\
\hline 4 & 298.1 & 0.9819 & 10.7 & 0.4284 & 104.5 & 102.7 & 0.001637 & -0.05845 \\
\hline 5 & 261.8 & 0.9819 & 2.7 & 0.4714 & 104.5 & 88.41 & 0.05956 & -0.09877 \\
\hline 6 & 278.1 & 0.9819 & 2.7 & 4.701 & 1223 & 1099 & 0.4597 & -0.5456 \\
\hline 7 & 298.1 & 0.34 & 2.7 & 0.2737 & -98.43 & -98.74 & 0.001135 & -22.25 \\
\hline 8 & 298.1 & 0.34 & 2.7 & 0.2737 & -98.43 & -98.74 & 0.001135 & -22.25 \\
\hline 9 & 302.6 & 0.3998 & 10.7 & 0.3095 & -96.19 & -97.43 & 0.001164 & -23.32 \\
\hline 10 & 302.6 & 0.3998 & 10.7 & 0.3095 & -96.19 & -97.43 & 0.001164 & -23.32 \\
\hline
\end{tabular}

rate of refrigerant passing through the condenser as well as absorber which improves the COP of the system. However, behavior of exergy efficiency can be explained by the fact that although the system with higher generator temperature can generate more refrigerant vapors, more input exergy is supplied and hence generate more exergy losses in the generator which contributes in increasing exergy efficiency of the system. 


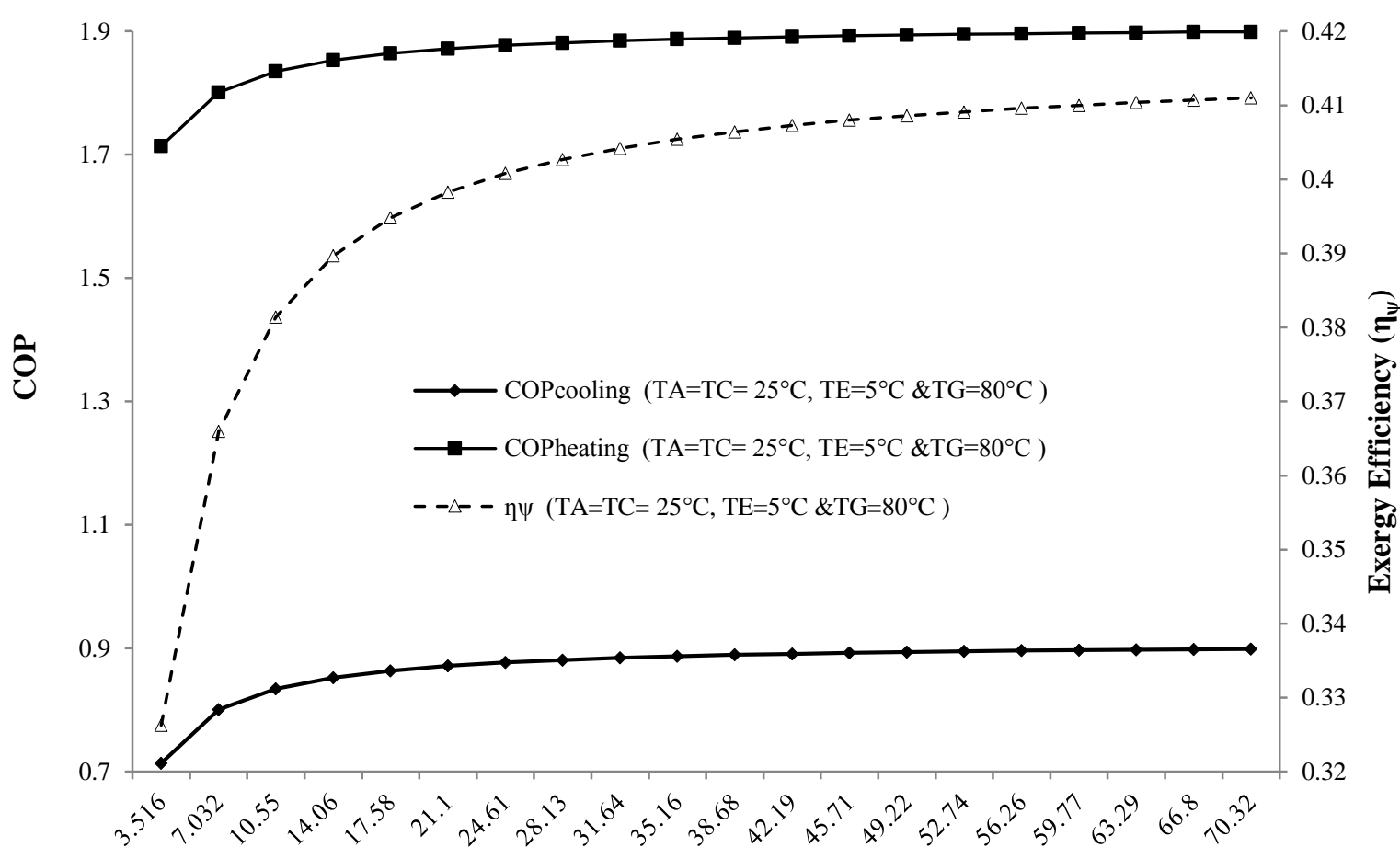

Cooling Capacity $(\mathrm{kW})$

Figure 2. Variation of COP and Exergy efficiency of a single- effect system with cooling capacities at maximum generator temperature $\left(\mathrm{T}_{\mathrm{E}}=5^{\circ} \mathrm{C} \& \mathrm{~T}_{\mathrm{A}}=\mathrm{T}_{\mathrm{C}}=25^{\circ} \mathrm{C}\right)$

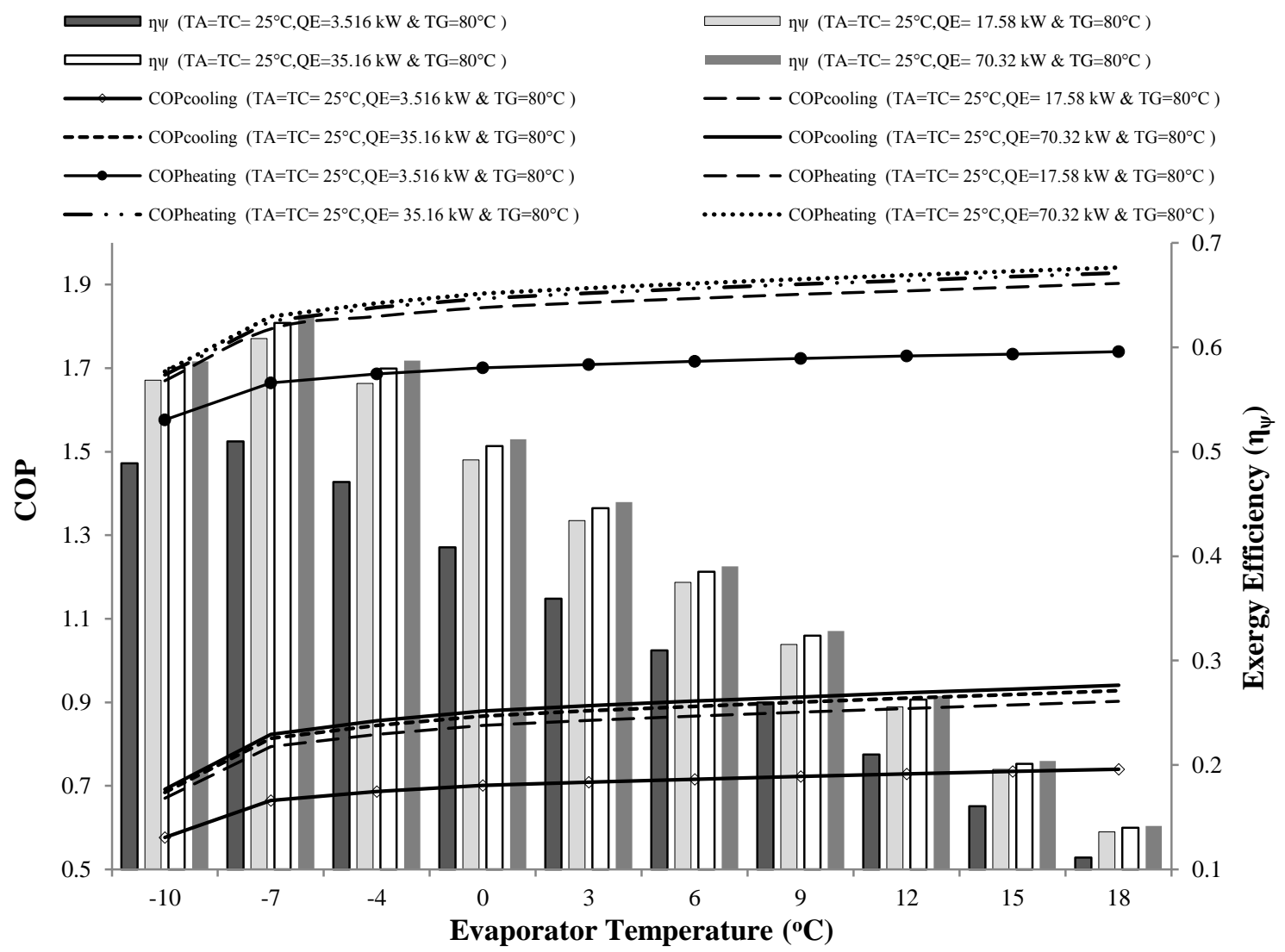

Figure 3. Variation of $\mathrm{COP}$ and Exergy efficiency of a single- effect system with evaporator temperature for different cooling capacities at maximum generator temperature $\left(\mathrm{T}_{\mathrm{G}}=80^{\circ} \mathrm{C} \& \mathrm{~T}_{\mathrm{A}}=\mathrm{T}_{\mathrm{C}}=25^{\circ} \mathrm{C}\right)$ 


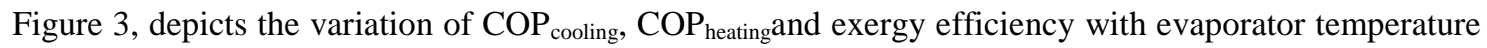
$\left(\mathrm{T}_{\mathrm{A}}=\mathrm{T}_{\mathrm{C}}=25^{\circ} \mathrm{C} \& \mathrm{~T}_{\mathrm{G}}=80^{\circ} \mathrm{C}\right)$ at maximum generator temperature for different cooling capacities and it becomes evident from figure that both $\mathrm{COP}_{\text {cooling }}$ and $\mathrm{COP}_{\text {heating }}$ shows an increasing trend and the maximum value of both $\mathrm{COP}_{\text {cooling }}$ and $\mathrm{COP}_{\text {heating }}$ is found to be at cooling capacity of $20 \mathrm{TR}$. However, an increase is not very much sharp and becomes almost constant at higher evaporator temperatures. This behavior can be explained on the fact that higher evaporator temperature will cause higher absorbing pressure which in turn greatly increases the absorption efficiency of the strong solution leading to an increase in the performance of system. However, exergy efficiency shows a decreasing trend with an increase in evaporator temperature and maximum value of exergy efficiency is found to be at cooling capacity of $20 \mathrm{TR}$. This can be explained on the fact that that low evaporator temperature has great potential to produce cooling as explained by second law of thermodynamics in Equation 21.

The variation of $\mathrm{COP}_{\text {cooling, }} \mathrm{COP}_{\text {heating }}$ and exergy efficiency with absorber and condenser temperature $\left(\mathrm{T}_{\mathrm{E}}\right.$ $=5^{\circ} \mathrm{C}, \mathrm{T}_{\mathrm{G}}=80^{\circ} \mathrm{C} \&$ cooling capacity $=3.516 \mathrm{~kW}$ ) is shown in Figure 4 and it becomes evident from the figure that $\mathrm{COP}_{\text {cooling, }} \mathrm{COP}_{\text {heating }}$ and exergy efficiency shows a decreasing trend. The reason for this behavior is that as the condenser and absorber temperature increases, the system pressure in generator will increase, as a result, lesser ammonia vapor are allowed to release from generator, thereby decreasing the COP as well as exergy

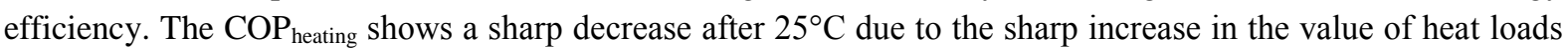
in the numerator as well as denominator in Equation 6. The $\mathrm{COP}_{\text {cooling }}$ and exergy efficiency also shows a sharp decrease after $25^{\circ} \mathrm{C}$ due to the sharp increase in the value of heat load in denominator in Equation 5.

However, variation in $\mathrm{COP}_{\text {cooling, }} \mathrm{COP}_{\text {heating }}$ and exergy efficiency with absorber and condenser temperature for different cooling capacities (Figure5) at maximum generator temperature revealed that maximum $\mathrm{COP}_{\text {cooling, }} \mathrm{COP}_{\text {heating }}$ and exergy efficiency is obtained at higher cooling capacity which goes on decreasing with an increase in an absorber as well as condenser temperature. Also, variation of $\mathrm{COP}_{\text {cooling, }}$

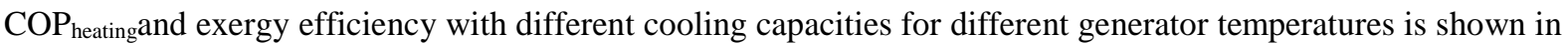
Figure $6\left(\mathrm{~T}_{\mathrm{E}}=5^{\circ} \mathrm{C} \& \mathrm{~T}_{\mathrm{A}}=\mathrm{T}_{\mathrm{C}}=25^{\circ} \mathrm{C}\right)$ and it becomes evident from the figure that $\mathrm{COP}_{\text {cooling, }} \mathrm{COP}_{\text {heating }}$ and exergy efficiency with an increase in cooling capacity shows an increasing trend. The $\mathrm{COP}_{\text {cooling, }} \mathrm{COP}_{\text {heating }}$ and exergy efficiency shows the maximum value for cooling capacity of $20 \mathrm{TR}$ at generator temperature of $80^{\circ} \mathrm{C}$. The curve showing an increase in the value of both $\mathrm{COP}_{\text {cooling }} \& \mathrm{COP}_{\text {heating }}$ becomes almost flat at higher cooling capacities. Also, exergy efficiency shows an increasing trend with an increase in the cooling capacity for different generator temperatures. The maximum exergy efficiency is found to be at lower generator temperature.

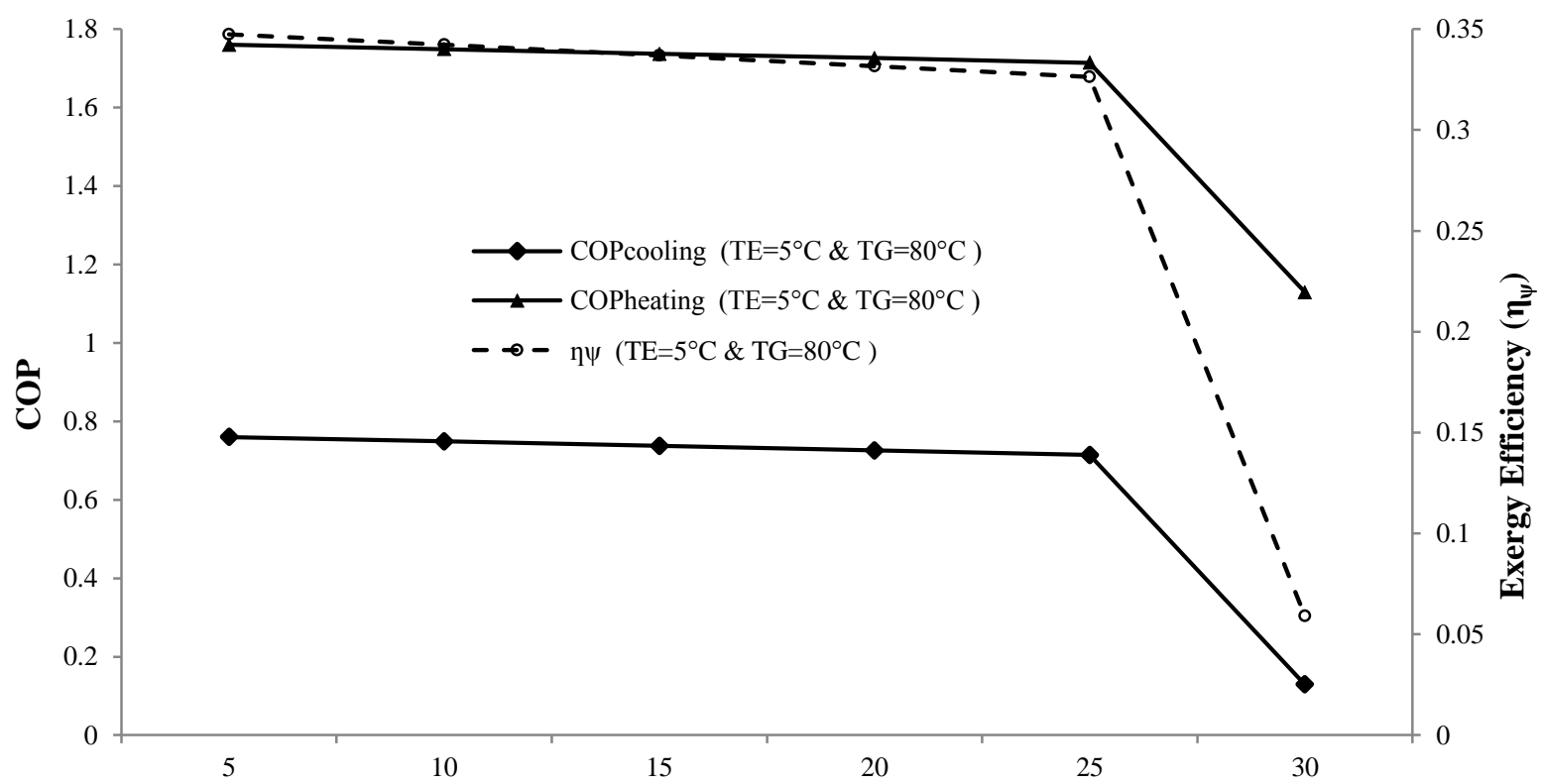

Absorber \& Condenser Temperature $\left({ }^{\circ} \mathrm{C}\right)$

Figure 4. Variation of COP and Exergy efficiency of a single- effect system with absorber \& condenser temperature at maximum generator temperature $\left(\mathrm{T}_{\mathrm{E}}=5^{\circ} \mathrm{C}, \mathrm{T}_{\mathrm{G}}=80^{\circ} \mathrm{C} \&\right.$ cooling capacity $\left.=3.516 \mathrm{~kW}\right)$ 


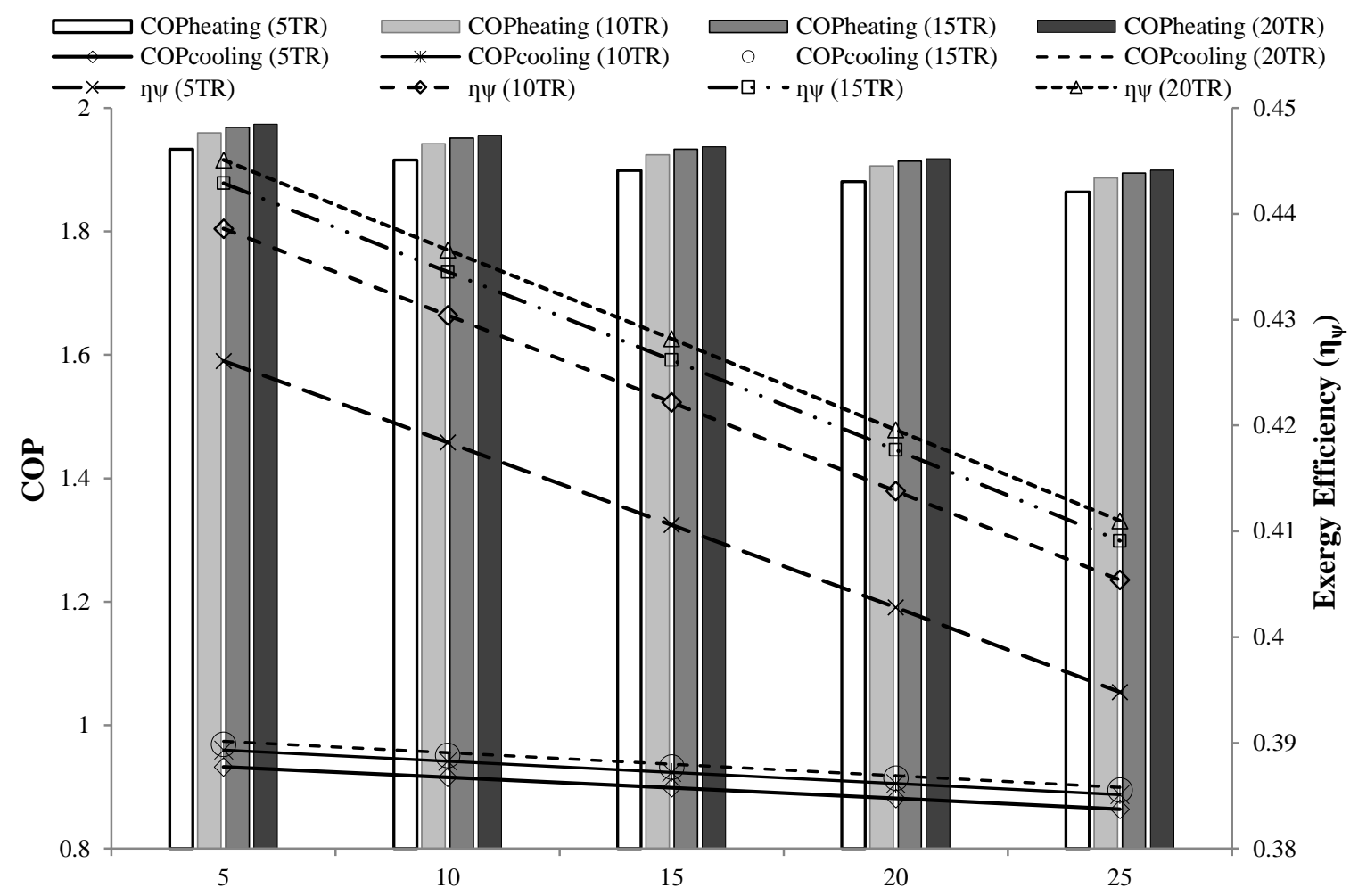

Absorber and Condenser Temperature $\left({ }^{\circ} \mathrm{C}\right)$

Figure 5. Variation of $\mathrm{COP}$ and Exergy efficiency of a single- effect system with absorber \& condenser temperature at different cooling capacities at maximum generator temperature $\left(\mathrm{T}_{\mathrm{E}}=5^{\circ} \mathrm{C} \& \mathrm{~T}_{\mathrm{G}}=80^{\circ} \mathrm{C}\right)$

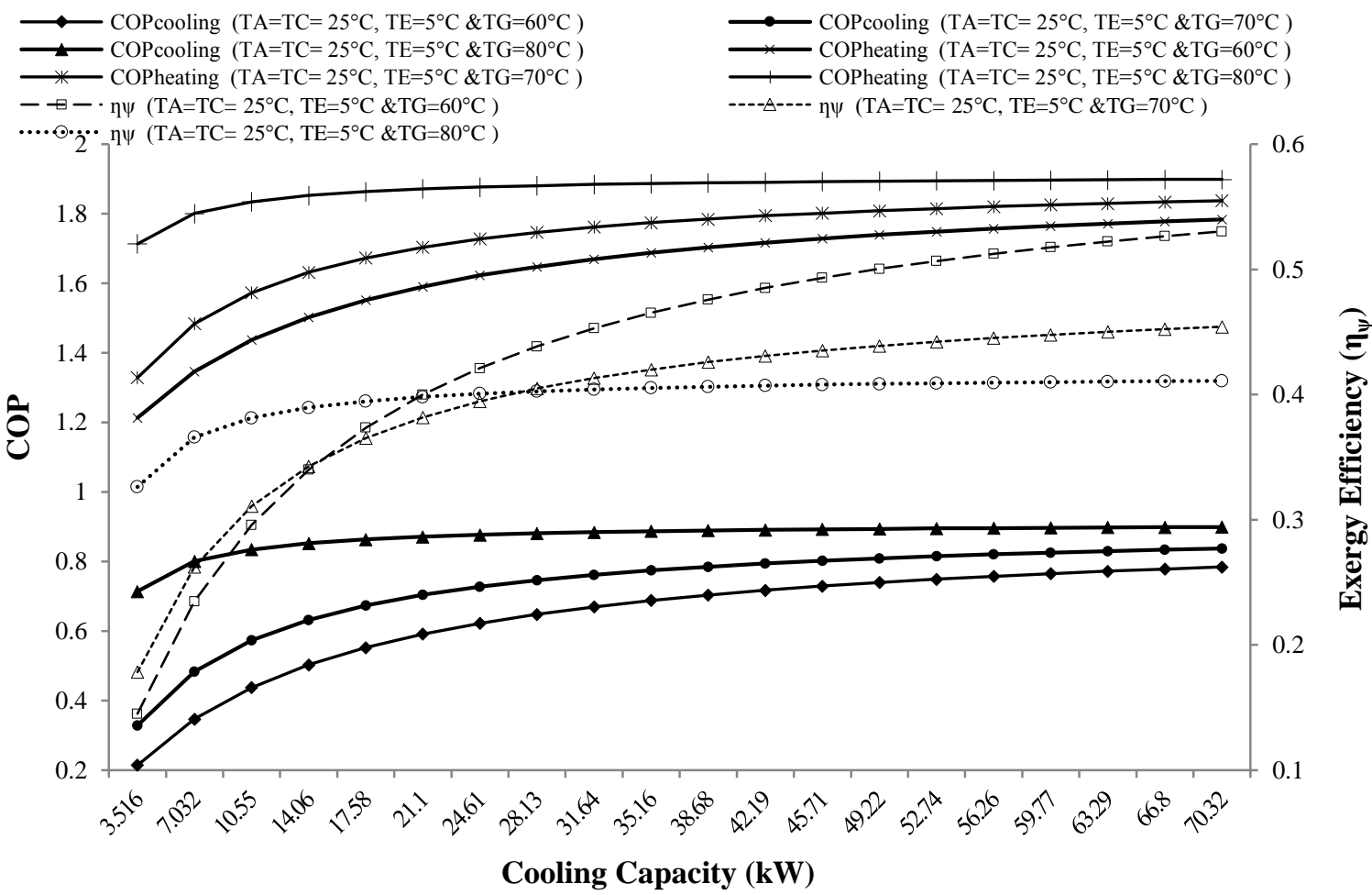

Figure 6. Variation of COP and Exergy efficiency of a single- effect system with cooling capacity for different generator temperatures $\left(\mathrm{T}_{\mathrm{E}}=5^{\circ} \mathrm{C} \& \mathrm{~T}_{\mathrm{A}}=\mathrm{T}_{\mathrm{C}}=25^{\circ} \mathrm{C}\right)$ 


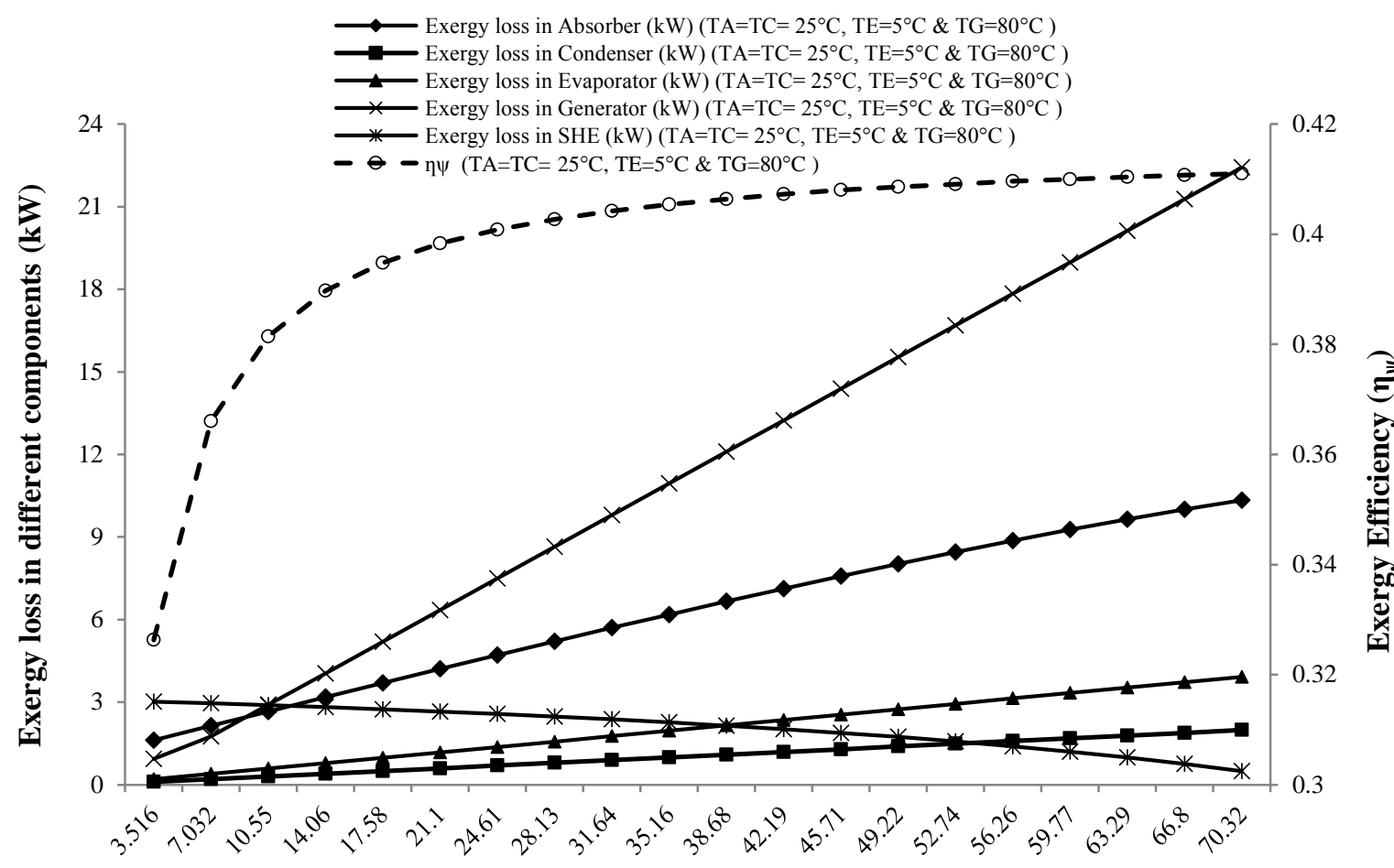

Cooling Capacity $(\mathrm{kW})$

Figure 7. Variation of Exergy loss in different components and Exergy efficiency of a single- effect system with cooling capacity at maximum generator temperature $\left(\mathrm{T}_{\mathrm{E}}=5^{\circ} \mathrm{C}, \mathrm{T}_{\mathrm{A}}=\mathrm{T}_{\mathrm{C}}=25^{\circ} \mathrm{C} \& \mathrm{~T}_{\mathrm{G}}=80^{\circ} \mathrm{C}\right)$

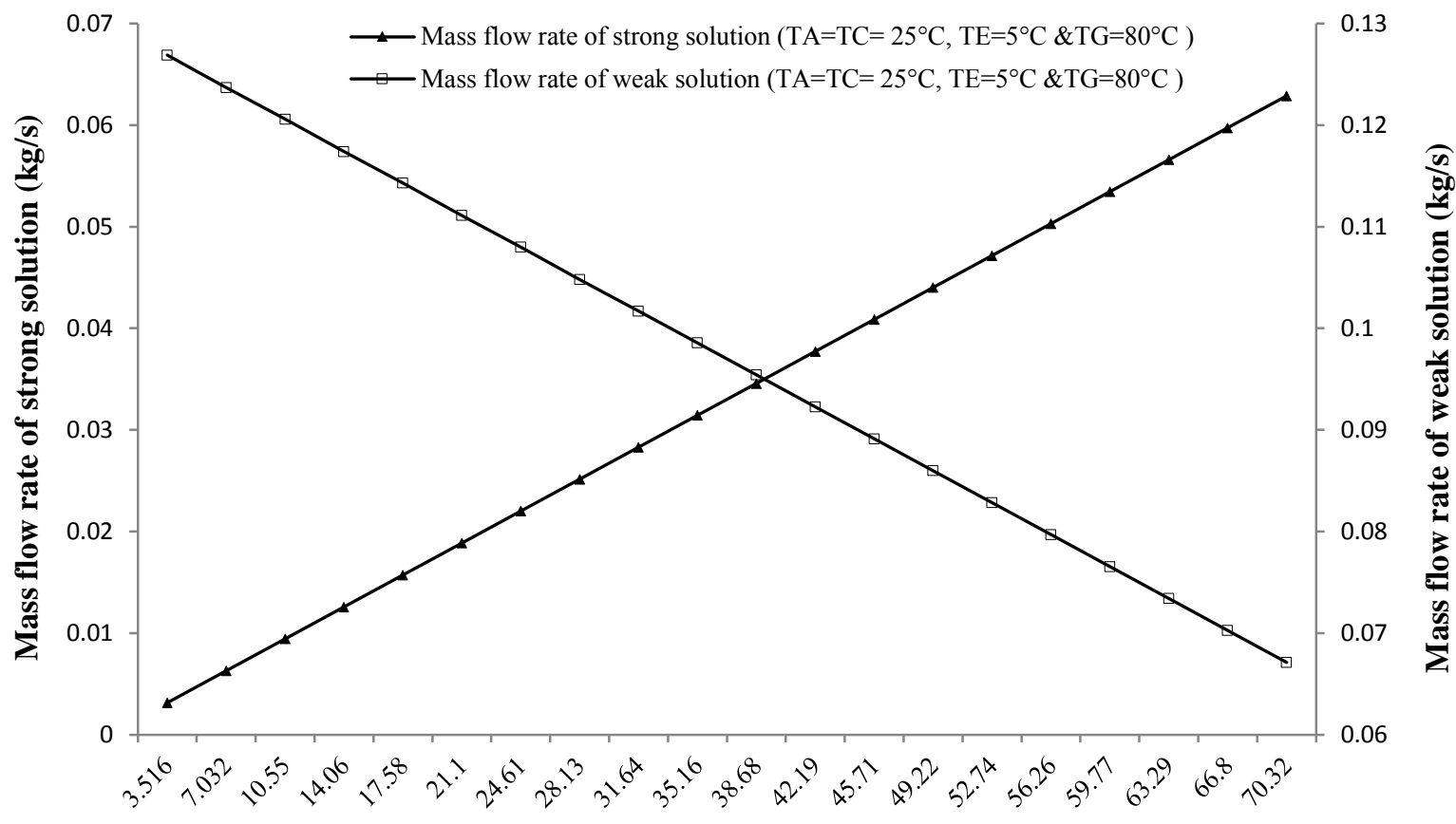

Cooling Capacity (kW)

Figure 8. Variation of Mass flow rate of strong solution and weak solution of a single- effect system with cooling capacity at maximum generator temperature $\left(\mathrm{T}_{\mathrm{E}}=5^{\circ} \mathrm{C}, \mathrm{T}_{\mathrm{A}}=\mathrm{T}_{\mathrm{C}}=25^{\circ} \mathrm{C} \& \mathrm{~T}_{\mathrm{G}}=80^{\circ} \mathrm{C}\right)$ 
Figure 7, shows the variation of exergy loss in different components as well as exergy efficiency with cooling capacity at maximum generator temperature $\left(\mathrm{T}_{\mathrm{A}}=\mathrm{T}_{\mathrm{C}}=25^{\circ} \mathrm{C}, \mathrm{T}_{\mathrm{G}}=80^{\circ} \mathrm{C} \& \mathrm{~T}_{\mathrm{E}}=5^{\circ} \mathrm{C}\right)$ and it becomes evident from the figure that variation in cooling capacity affects the exergy loss in different components as well as exergy efficiency of the absorption refrigeration system. The maximum exergy loss is found to be in the solution heat exchanger followed by absorber, generator, evaporator and condenser. However, exergy loss in solution heat exchanger shows descending trend with an increase in cooling capacity of the system while exergy loss in absorber, generator, evaporator and condenser is found to show ascending trend with an increase in cooling capacity of the system. The exergy efficiency also shows an increasing trend with an increase in cooling capacity which becomes almost constant at higher cooling capacity.

The variation of mass flow rate of strong solution and weak solution with cooling capacity $\left(\mathrm{T}_{\mathrm{E}}=5^{\circ} \mathrm{C}\right.$, $\mathrm{T}_{\mathrm{A}}=\mathrm{T}_{\mathrm{C}}=25^{\circ} \mathrm{C} \& \mathrm{~T}_{\mathrm{G}}=80^{\circ} \mathrm{C}$ ) is shown in Figure 8 above and it becomes evident that with an increase in cooling capacity of the system, mass flow rate of the strong solution increases while mass flow rate of weak solution decreases. However, figure 9, shows the variation of exergy loss in different components as well as exergy efficiency with ambient temperature $\left(\mathrm{T}_{\mathrm{E}}=5^{\circ} \mathrm{C}, \mathrm{T}_{\mathrm{A}}=\mathrm{T}_{\mathrm{C}}=25^{\circ} \mathrm{C}, \mathrm{T}_{\mathrm{G}}=65^{\circ} \mathrm{C} \&\right.$ cooling capacity $\left.=3.516 \mathrm{~kW}\right)$ and it becomes evident from the figure that maximum exergy loss is found to be in generator followed by solution heat exchanger absorber, evaporator and condenser. However, exergy loss in solution heat exchanger and generator shows descending trend with an increase in ambient temperature while exergy loss in absorber, evaporator and condenser show ascending trend with an increase in ambient temperature. The exergy efficiency also shows an increasing trend with an increase in ambient temperature and the same is happening because ambient temperature directly influences exergy efficiency as shown in Equation 21. An increase in ambient temperature directly affects the heat load of the components of absorption system thereby increasing the exergy efficiency.

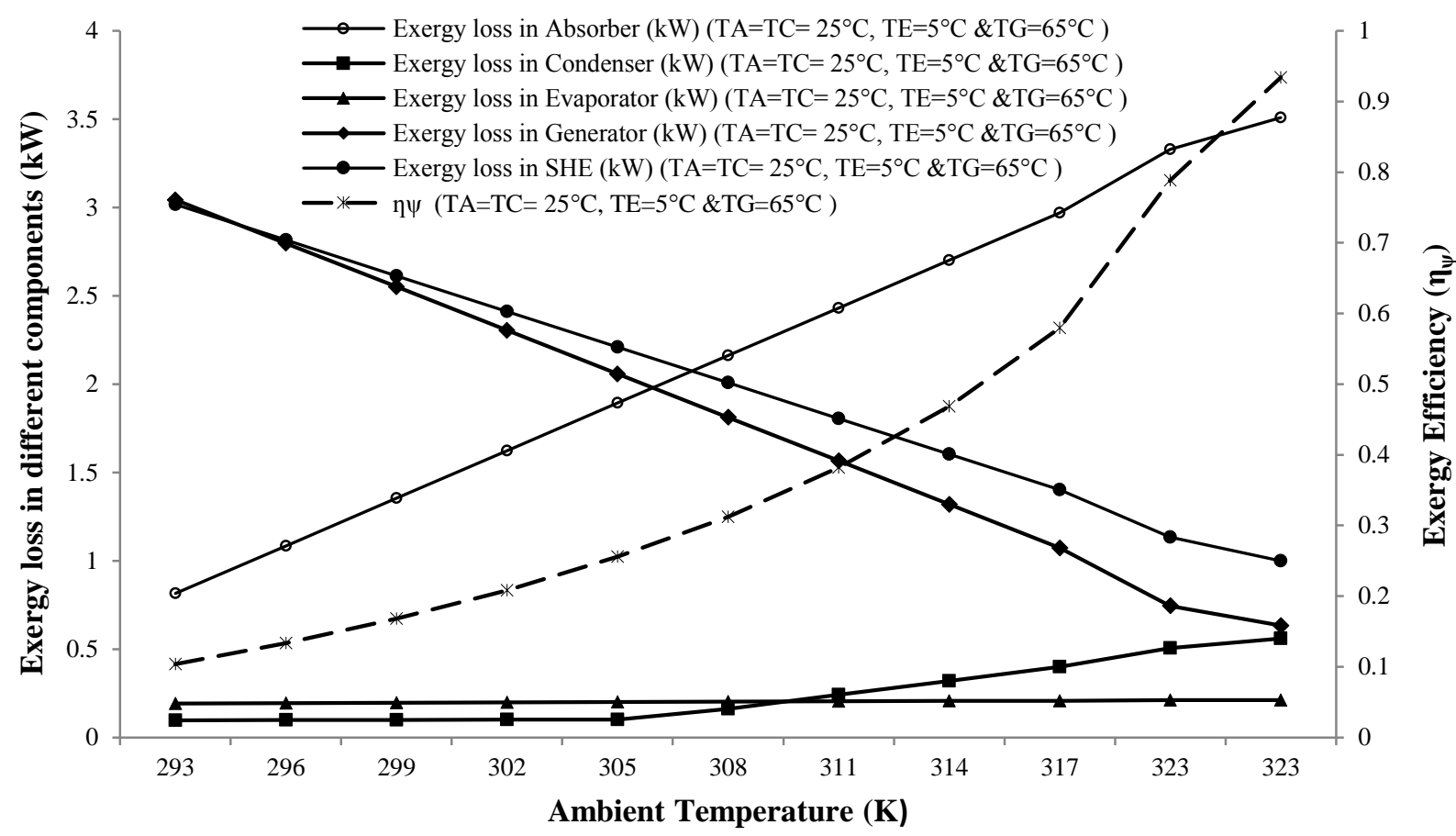

Figure 9. Variation of Exergy loss in different components and Exergy efficiency of a single- effect system with ambient temperature $\left(\mathrm{T}_{\mathrm{E}}=5^{\circ} \mathrm{C}, \mathrm{T}_{\mathrm{A}}=\mathrm{T}_{\mathrm{C}}=25^{\circ} \mathrm{C}, \mathrm{TG}=65^{\circ} \mathrm{C} \&\right.$ cooling capacity $\left.=3.516 \mathrm{~kW}\right)$

\section{CONCLUDING REMARKS}

A computer program using EES [32] has been developed to investigate the performance of a single-effect ammonia-water vapor absorption system as an option for heating and cooling in building using the concept of 
energy as well as exergy. The exergy analysis shows that different operating parameters affect the performance of system. It has also been concluded that variation in cooling capacity is also found to influence COP, exergy loss in different components as well as exergy efficiency. The values of $\mathrm{COP}_{\text {cooling }}$ and $\mathrm{COP}_{\text {heating }}$ lie in the range of 0.71-0.89 and 1.71-1.89 respectively, for the cooling capacity variation from $1 \mathrm{TR}$ to $20 \mathrm{TR}$, at maximum working generator temperature of $80^{\circ} \mathrm{C}$. However, exergy efficiency of the system lies in the range of 0.32-0.41 for the same variation in cooling capacities ranging from 1 TR to $20 \mathrm{TR}$ at maximum working generator temperature of $80^{\circ} \mathrm{C}$. It has also established that with an increase in evaporator temperature and at maximum cooling capacity both $\mathrm{COP}_{\text {cooling }}$ and $\mathrm{COP}_{\text {heating }}$ shows an increasing trend. The $\mathrm{COP}$ as well as exergy efficiency also shows the maximum value at the highest cooling capacity. The irreversibility rate in absorber in comparison to condenser is found to be more which is the actual case. It is worth to mention, that design improvements in generator and absorber have the potential to improve performance of the system. There is also a need is to improve the effectiveness of solution heat exchanger. The results obtained revealed that such system can easily be applied to the building systems for attaining thermal comfort and achieve passive cooling. It has also been concluded that application of solar and waste energy in the cooling technologies can be adopted for sustainable future as well as to overcome the climate and environmental concerns.

\section{NOMENCLATURE}

$\begin{array}{ll}\dot{m} & \text { Mass flow rate of refrigerant }[\mathrm{kg} / \mathrm{s}] \\ h & \text { Specific Enthalpy }[\mathrm{kJ} / \mathrm{kg}] \\ S & \text { Specific Entropy }[\mathrm{kJ} / \mathrm{kg}-\mathrm{K}] \\ \dot{Q} & \text { Heat flow rate }[\mathrm{kW}] \\ p & \text { Pressure }[\mathrm{bar}] \\ \mathrm{T} & \text { Temperature }\left[{ }^{\circ} \mathrm{C} / \mathrm{K}\right] \\ \dot{W} & \text { Power consumption rate }[\mathrm{kW}] \\ x & \text { Concentration of ammonia in solution } \\ 1-10 & \text { Different state points in a system } \\ \text { PR-valve } & \text { Pressure reducing valve } \\ \text { COP } & \text { Coefficient of Performance } \\ \text { EES } & \text { Engineering Equation Solver } \\ \Psi & \text { Exergy [kW] } \\ \eta & \text { Efficiency } \\ \epsilon & \text { Effectiveness of heat exchanger } \\ \text { A } & \text { Absorber } \\ \text { C } & \text { Condenser } \\ \mathrm{G} & \text { Generator } \\ \mathrm{G}-\mathrm{II} & \text { Generator } \\ \mathrm{E} & \text { Evaporator } \\ P & \text { Pump } \\ o & \text { Ambient, Outside } \\ i & \text { Inlet } \\ \text { SHE } & \text { Solution Heat Exchanger } \\ & \end{array}$

\section{REFERENCES}

[1] Ventas, R., Lecuona, A., Vereda, C., Legrand, M. (2016). Two-stage double-effect ammonia/lithium nitrate absorption cycle. Applied Thermal Engineering, 94, 228 - 237.

[2] Siddiqui, M. U., Said, S. A. M. (2015). A review of solar powered absorption systems. Renewable and Sustainable Energy Reviews, 42,93 - 115.

[3] Pintaldi, S. S., Taylor, R. A., White, S. D., Morrison, G. L., Rosengarten, G. (2015). Solar-Powered Absorption Chillers for Air-Conditioning Applications: Simulation and Techno-Economic Evaluation, In Proceedings of 9th International Conference on Energy Sustainability, collocated with ASME 2015 Power 
Conference, 13th ASME International Conference on Fuel Cell Science, Engineering and Technology, and the ASME 2015 Nuclear Forum, American Society of Mechanical Engineers.

[4] Ghafoor, A., Munir, A. (2015). World-wide overview of solar thermal cooling technologies. Renewable and Sustainable Energy Reviews, 43, 763-774.

[5] Lange, M. F. D., Verouden, K. J. F. M., Vlugt, T. J. H., Gascon, J., Kapteijn, F. (2015). Adsorption-driven heat pumps: the potential of metal-organic frameworks. Chemical Reviews, 115(22), 12205 - 12250.

[6] Sabek, S., Nasr, K. B., Chouikh, R., Guizani, A. (2015). Analytical Study of a Heat Recovery/Desiccant Cooling System under Tunisian Climatic Conditions. Journal of Clean. Energy Technologies, 3(3), 159 - 164.

[7] Sultana, P., Wijeysundera, N. E., Ho, J. C., Yap, C., Chang, T. K. (2015). Effect of vapour absorption enhancement in solar-heat driven air-conditioning system. Journal of Clean Energy Technologies, 3(1), 43 - 47.

[8] Quan, S. H., Xu, Z. Y., Wang, H., Wang, R. (2015). A solar/gas fired absorption system for cooling and heating in a commercial building. Energy Procedia, 70, 518 - 528.

[9] Li, Y., Hu, R. (2016).Exergy-analysis based comparative study of absorption refrigeration and electric compression refrigeration in CCHP systems. Applied. Thermal. Engineering, 93, 1228 - 1237.

[10] Al-Ugla, A. A., El-Shaarawi, M. A. I., Said, S. A. M., Al-Qutub, A. M. (2016). Techno-economic analysis of solar-assisted air-conditioning systems for commercial buildings in Saudi Arabia.Renewable and Sustainable Energy Reviews,54, 1301-1310.

[11] Gupta, A., Anand, Y., Anand, S., Tyagi, S. K. (2015). Thermodynamic optimization and chemical exergy quantification for absorption-based refrigeration system. Journal of Thermal Analysis and Calorimetry, 122 (2), 893-905.

[12] Abdullah, M. O., Hien, T. C. (2010). Comparative analysis of performance and techno- economics for a H2O-NH3-H2 absorption refrigerator driven by different energy sources. Applied Energy, 87(5),1535 - 1545.

[13] Arora, A., Dixit, M., Kaushik, S. C. (2016). Energy and exergy analysis of a double effect parallel flow $\mathrm{LiBr} / \mathrm{H} 2 \mathrm{O}$ absorption refrigeration system. Journal of Thermal Engineering, 2(1), $541-549$.

[14] Xu, X., Vignarooban, K., Xu, B., Hsu, K., Kannan, A. M. (2016). Prospects and problems of concentrating solar power technologies for power generation in the desert regions. Renewable and Sustainable Energy Reviews, 53, $1106-1131$.

[15] Sanjuan, C., Soutullo, S., Heras, M. R. (2010). Optimization of a solar cooling system with interior energy storage. Solar Energy, 84 (7), 1244-1254.

[16] Anand, S., Gupta, A., Tyagi, S. K. (2014). Renewable energy powered evacuated tube collector refrigerator system. Mitigation and Adaptation Strategies for Global Change, 19(7), 1077-1089.

[17] Gong, S., Boulama, K.G. (2015). Advanced exergy analysis of an absorption cooling machine: Effects of the difference between the condensation and absorption temperatures. International Journal of Refrigeration, 59, $224-234$.

[18] Pilatowsky, I., Rivera, W., Romero, R. J. (2001). Thermodynamic analysis of monomethylamine-water solution in a single stage solar absorption refrigeration cycle at low generator temperatures. Solar Energy Material and Solar Cells, 70(3), 287-300.

[19] Lostec, B. L., Galanis, N., Millette, J. (2012). Experimental study of an ammonia-water absorption chiller. International Journal of Refrigeration, 35(8), 2275 -2286.

[20] Kaynakli, O., Saka, K., Kaynakli, F. (2015). Energy and exergy analysis of a double effect absorption refrigeration system based on different heat sources. Energy Conversion and Management, 106, 21 - 30.

[21] Vaibhav, J., Sachdeva, G., Kachhwaha, S. S. (2015).Thermodynamic modelling and parametric study of a low temperature vapour compression-absorption system based on modified Gouy-Stodola equation. Energy, 79, $407-418$.

[22] Adewusi, S. A., Zubair, S. M. (2004). Second law based thermodynamic analysis of ammonia-water vapor absorption refrigeration system. Energy Conversion and Management, 45 (15), 2355 - 2369.

[23] Ezzine, N. B., Barhoumi, M., Mejbri, K., Chemkhi, S.,Bellagi, A. (2004). Solar cooling with the absorption principle: first and Second Law analysis of an ammonia-water double-generator absorption chiller. Desalination, 168, 137-144.

[24] Paurine, A., Maidment, G. G., Eames, I. W., Missenden, J. F. (2012). Development of a thermo-gravity pumping mechanism for circulating the working fluids in a novel $\mathrm{LiBr}-\mathrm{H} 2 \mathrm{O}$ vapor absorption refrigeration (VAR) system. Applied Thermal Engineering, 47, 25-33. 
[25] Roy, S., Maiya, M. P. (2013). Analysis of pinch point in liquid-vapour heat exchanger of R134aDMAC vapour absorption refrigeration system. Applied Thermal Engineering, 50(2), 1619-1626.

[26] Suresh, M., Mani, A. (2013). Heat and mass transfer studies on a compact bubble absorber in R134a-DMF solution based vapour absorption refrigeration system. International Journal of Refrigeration, 36(3), 1004 1014.

[27] Swarnkar, S. K., Murthy, S. S., Gardas, R. L., Venkatarathnam, G. (2014). Performance of a vapour absorption refrigeration system operating with ionic liquid-ammonia combination with water as co-solvent. Applied Thermal Engineering, 72(2), 250-257.

[28] Buckmaster D. J., Abramson, A. R. (2015). Characterization of the effects of insulating wall paint on space conditioning in a room. Journal of Thermal Engineering, 1(1), 322-329.

[29] Anand, Y., Gupta, A., Maini, A., Gupta, A., Sharma, A., Khajuria, A., Gupta, S., Sharma, S., Anand, S.,Tyagi, S. K. (2014). Comparative Thermal Analysis of Different Cool Roof Materials for Minimizing Building Energy Consumption. Journal of Engineering.

[30] Doseva, N., Chakyrova, D. (2015). Energy and exergy analysis of cogeneration system with biogas engines. Journal of Engineering, 1(3), 391-401.

[31] Anand, S., Gupta, A., Tyagi, S.K. (2013). Thermodynamic analysis of 1 TR biogas based NH3-H2O vapor absorption system, In proceedings of Recent Advances in Bio-Energy Research, 2, 79 - 98.

[32] Klein, S. A., Alvarado, F. (2013). Engineering Equation Solver, Version 9.462, F-Chart Software: Middleton, WI. 